\title{
CIVIL PROCEDURE BEYOND NATIONAL BORDERS
}

\author{
Cornelis H. van Rhee \\ Professor of European Legal History \\ and Comparative Civil Procedure, \\ Maastricht University (Maastricht, the Netherlands)
}

Summary: 1. Introduction. - 2. Harmonisation as a Result of National Law Reform. - 3. Harmonisation as a Result of Competition between Procedural Systems. - 4. Intended Harmonisation. - 5. Final Remarks.

The present paper focuses on the harmonisation of civil procedural law in Europe and on a global scale. As the title of the paper indicates, this will be done by also taking into consideration past experiences in this field. The question as to the desirability of harmonisation will not be discussed. The paper will especially focus on (1) Harmonisation as a result of national law reform, (2) Harmonisation as a result of competition between procedural systems, and (3) Harmonisation as a result of international harmonisation projects.

Key words: harmonisation of civil procedure, national law reform, procedural systems, international harmonisation projects.

\section{INTRODUCTION}

A first glance at the various civil procedural systems of our modern world shows considerable disparities. One of the explanations for this is often found in the historical differences in the approach to civil litigation in what may be called the Common Law and Civil Law families of civil procedure. ${ }^{32}$ However, this explanation may not be sufficient anymore, since even within the two main families of civil procedure the differences are sometimes large. It has even been stated that because of this the dichotomy between Civil Law and Common Law may have lost much of its relevance. ${ }^{33}$ The truth of this statement may be demonstrated by comparing

32 R Van Caenegem, 'History of European Civil Procedure', International Encyclopedia of Comparative Law (2005) Vol XVI 16-23; C H van Rhee, 'Introduction' in C H Van Rhee (ed) European Traditions in Civil Procedure (Intersentia 2005) 3-23.

33 N Andrews, A Modern Procedural Synthesis: The American Law Institute and UNIDROIT's 'Principles and Rules of Transnational Civil Procedure' (Tijdschrift voor Civiele Rechtspleging 2009) 52: 'This project [i.e. the ALI/Unidroit Priniciples of Transnational Civil Procedure] also shows that a jurisdiction's historical association with the Common Law or Civil Law tradition is 
England and Wales (shortly 'England' hereafter) and the United States of America. As all comparative procedural lawyers will know, in England the jury has nearly disappeared from civil trials, ${ }^{34}$ whereas the right to a jury trial is a constitutional right in the US. ${ }^{35}$ It is also a known fact that the role of pre-trial discovery (currently known as disclosure in England) is radically different in these two jurisdictions. Whereas discovery in the US is still rather extensive, at least from a European perspective, ${ }^{36}$ stringent limits have been introduced in England by the Woolf Reforms (1999). ${ }^{37}$ At the same time, it seems that the differences between jurisdictions from different procedural families are becoming less pronounced. ${ }^{38}$ When one compares modern English civil procedure with the procedure of various continental European jurisdictions, it appears, for example, that both in England and in large parts of the Continent the judge has become an active case manager in civil proceedings, albeit in England mainly as regards the formal aspects of litigation, whereas the judge is also active as regards the content of the case in many Continental jurisdictions. ${ }^{39}$ In this respect, England has moved away from the traditional Common Law approach and in the direction of the European Continent. ${ }^{40}$ Additionally, various continental systems of civil procedure continue to demonstrate an interest in English procedural devices and rules, for example English style documentary discovery (disclosure) mechanisms (here one may refer to the recent reforms in civil procedure in Ukraine), even though such mechanisms are traditionally absent in these systems, a situation which has occasionally caused concern in some countries. In the Netherlands, a draft Civil Code from 1804 - part of civil procedure was regulated by the Civil Code in these days - already attempted to introduce very extensive duties for litigants and third parties to allow access to documents beneficial to the case of the opponent party,

not an immutable genetic stamp. Arguably, this backward-looking distinction will soon have lost any clear value in modern procedural structures.' And also: 'These differences [between the USA and English systems, and between the various civil law jurisdictions] make a nonsense of the glib phrase "Anglo-American procedure" and, especially, of the crude expression "Civilian procedure". See also E Storskrubb, Civil Procedure and EU Law. A Policy Area Uncovered (Oxford University Press 2008) 285, and N Trockner and V Varano, 'Concluding Remarks' in N Trockner and V Varano (eds) The Reforms of Civil Procedure in Comparative Perspective (Giappichelli Editore 2005) 243-247.

34 N Andrews, English Civil Procedure. Fundamentals of the New Civil Justice System (Oxford University Press 2003) nos 34.08 - 34.10; Supreme Court Act 1981, s69; R Stürner, The Principles of Transnational Civil Procedure: An Introduction to their Basic Conceptions (Rabels Zeitschrift 2005) para 201; C H van Rhee, 'English Civil Procedure Until the Civil Procedure Rules' in C H van Rhee (ed) European Traditions in Civil Procedure (Intersentia 1998) 129.

35 Seventh Amendment of the US Constitution.

36 W Burnham, Introduction to the Law and Legal System of the United States (Thomson/West 2006) 226-259.

37 Lord Woolf, Access to Justice: Final Report (HMSO 1996) para 37 ff; Andrews (n 34) nos 26.01 26.128 .

38 P H Lindblom, Harmony of Legal Spheres: A Swedish View on the Construction of a Unified European Procedural Law (European Review of Private Law 1997) 20.

39 Lord Woolf (n 37) s II; C H van Rhee, 'The Development of Civil Procedural Law in TwentiethCentury Europe: From Party Autonomy to Judicial Case Management and Efficiency' in C H van Rhee (ed), Judicial Case Management and Efficiency in Civil Litigation (Intersentia 2008) 11-25.

40 C H van Rhee, 'Towards a Procedural Ius Commune?' in J Smits and G Lubbe (eds), Remedies in Zuid-Afrika en Europa (Intersentia 2003) 217-232. See for an overview of the major similarities and differences between the world's civil procedural systems, ALI/UNIDROIT 2006, 4-7. 
even if the specific documents could only be identified in a very inexact manner, ${ }^{41}$ whereas Franz Klein, the famous Austrian law reformer, referred to discovery as a beneficial procedural device in his Pro Futuro, published in the $1890 \mathrm{~s} .{ }^{42}$ Due to the increasing conviction in many countries that civil judgments should be based on the substantive truth instead of the truth as fabricated by the parties only, it is not unlikely that documentary discovery will soon be part of most modern Continental civil procedural codes. ${ }^{43}$ This will obviously result in a move of Continental procedural systems in the direction of England, at least in this particular respect.

In the present paper I will focus on the prospects of the harmonisation of civil procedural law in the future. As the title of my paper indicates, I will also do this by taking into consideration past experiences in this field. The question as to the desirability of harmonisation will not be discussed in depth here. ${ }^{44}$

I will focus on three types of harmonisation:

1) Harmonisation as a result of national law reform;

2) Harmonisation as a result of competition between procedural systems;

3) Harmonisation as a result of international harmonisation projects.

\section{HARMONISATION AS A RESULT OF NATIONAL LAW REFORM}

Some procedural systems have a tendency to become more alike - at least as regards the civil procedure rules, i.e. black latter law - even though this is not the primary aim of the Legislature or other rule-making authorities. This is due to the fact that

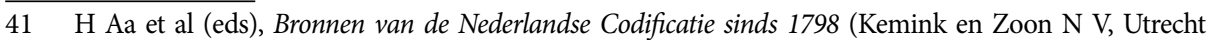
1968) vol I 459-461: (Ontwerp-Cras 1804): Art 55. 'Gelijk elk verpligt is, daar toe behoorlijk geroepen zijnde, getuigenis der waarheid te geven, zoo moet ook elk, die eenige bewijsstukken onder zich heeft, welke tot ontlasting of bezwaar, 't zij in burgerlijke, 't zij in misdadige zaken, strekken, dezelve aan den belanghebbenden, of die daar recht op hebben, uitreiken.' (Similar to the rule that everyone, who has been called to court in the prescribed manner, has to testify, also everyone who has any beneficial or detrimental documentary proof under him has to provide anyone with an interest in or an entitlement to these documents, with these very documents, both in criminal and in civil cases). However, even though this rule seems extremely broad, the defendant - but only the defendant - did, according to the draft, in most cases not have to disclose documents to the claimant; see Art 59. 'Gelijk, in het algemeen, de eisscher met het bewijs zijner vordering belast is, zonder dat de verweerder iets daar tegen behoeft te berde te brengen, zoo kan ook deze niet genoodzaakt worden, om de bewijzen, welke hij voor de vordering van den eisscher in zijnen boezem heeft over te geven.' (Similar to the rule that, generally speaking, the claimant has the burden of proof as regards his claim, without the need for the defendant to act in this respect, also the defendant cannot be obliged to disclose documents in his power which are beneficial for the claimant's case). After the draft has listed some exceptions to this rule, Art 62 states that in situations other than those listed as exceptions to the general rule, the judge has considerable discretion as regards the defendant's duty to disclose documents; see Art 62. 'In welke andere gevallen een gedaagde tot overgifte der brieven, welke bij hem berusten, gehouden zij, moet de rechter beoordeelen.' (In which other cases the defendant can be obliged to disclose documents has to be determined by the judge).

42 F Klein, Pro Futuro: Betrachtungen über Probleme der Civilprocessreform in Österreich (Franz Deuticke 1891) $41 \mathrm{ff}$.

43 On the introduction of discovery devices in some Continental jurisdictions, see also Trockner and Varano (n 33) 255-258; and R Verkerk, Fact-finding in Civil Litigation: A Comparative Perspective (Intersentia 2010) 37.

44 G P Miller, 'The Legal-Economic Analysis of Comparative Civil Procedure' (1997) 45 American Journal of Comparative Law 905. 
comparative civil procedure - explicitly or implicitly - has, since times immemorial, been used as a tool where attempts are made to reform a national procedural system. Such an approach may be wise since foreign experiences may offer information on the functioning of particular procedural rules in practice. An early example is the fifteenth and sixteenth century Low Countries, where explicit legislative attention for French-Burgundian procedural law resulted in a considerable alignment with that procedure. This proved to be the case not only as regards black letter law, but also as regards procedural practice, as appears from the history of various courts in the Low Countries, notably the so-called Great Council of Malines, one of the superior courts of that area in the early modern period. ${ }^{45}$ In more recent times, examples abound. Reference may be made to the nineteenth and twentieth century Netherlands $s^{46}$ and Belgium. ${ }^{47}$ Since implicit attention for foreign civil procedure i.e. attention which is not specifically mentioned by the Legislature, for example for political reasons - is more difficult to demonstrate and needs considerable additional research, the present paper will concentrate on examples of explicit attention.

A first question that may be addressed is which jurisdictions are usually studied in law reform projects. It appears that often the jurisdictions that are studied are related in one way or another to the system in need of reform as it is apparently thought that these jurisdictions offer examples that may be implemented in a relatively uncomplicated manner. There are, of course, exceptions to this rule, as is shown by the introduction of the German civil procedural legislation in Japan in 1890, as part of the law reform project started after the Meiji Restoration in $1868 .^{48}$ These exceptions are, however, rare and usually only occur when a whole legal systems is replaced in a single blow by another legal system and not when gradual law reform is contemplated, as is usually the case.

The relationship between the system in need of reform and the foreign legal system is usually the result of a close contact, not only in the procedural field but also as regards the law in general, the economy, politics and/or culture, between the various jurisdictions. The fifteenth century Low Countries, for example, were in various of these respects closely related to their French-Burgundian example (the Burgundian dukes ruling the Low Countries were a younger branch of the French royal house of Valois) and French influence continued - maybe surprisingly - in the sixteenth century under Habsburg rule. ${ }^{49}$ This is also true for the nineteenth century Netherlands and Belgium. The annexation of these territories by France had resulted in the introduction of French legislation. This legislation was not repealed after the defeat of Napoleon Bonaparte.

$45 \quad \mathrm{C} H$ van Rhee, Litigation and Legislation: Civil Procedure at First Instance in the Great Council for the Netherlands in Malines (1522-1559) (Archives générales du Royaume1997) $313 \mathrm{ff}$. See also C H van Rhee 'Civil Procedure: A European Ius Commune?' (2000) 8 (4) European Review of Private Law, 589-611.

46 A W Jongbloed, 'The Netherlands (1838-2005)' in C H Van Rhee (ed.), European Traditions in Civil Procedure (Ius Commune Europaeum 54), (Intersentia 2005) 69-95.

47 D Heirbaut, 'Efficiency: the Holy Grail of Belgian Justice?' in A Uzelac and C H Van Rhee (eds) Access to Justice and Judiciary: Towards New European Standards of Affordability, Quality and Efficiency of Civil Adjudication (Intersentia 2009) 89-117.

48 O G Chase et al (eds), Civil Litigation in Comparative Context (Thomson/West 2007) 35-36.

49 D P Blok et al (eds), Algemene Geschiedenis der Nederlanden, vol. IV (Unieboek B V Bussum 1980) $135 \mathrm{ff}$, and idem $311 \mathrm{ff}$. 
From a legal point of view (and, before the defeat of the French emperor at Leipzig, also from the political and economic perspective), the Netherlands and Belgium were integrated into the French legal system, something that especially in Belgium was reinforced by the French cultural and linguistic orientation of the elite of that country during the nineteenth and a large part of the twentieth century. Consequently, for Belgium it was only natural to look at French procedural law and contemporary French criticism of the French Code of Civil Procedure when far-reaching reforms to the Belgian Code of Civil Procedure were contemplated in the second half of the nineteenth century (other foreign influences were at that time less important and restricted to countries which were still influenced by France even though they had their own codifications: Geneva, the Netherlands and the Kingdom of Italy $)^{50}$ and again in the second half of the twentieth century when reforms were actually introduced (at this time the list of relevant jurisdictions other than France was considerably longer, even though French influence remained dominant). ${ }^{51}$ The same is true for the Netherlands. This country introduced its own civil procedural code in 1838 which showed a strong French influence. In later reform projects, the Dutch lawmaker looked at other jurisdictions, notably Austria and Germany at the start of the twentieth century, ${ }^{52}$ and England and Wales at the start of the twenty-first century. ${ }^{53}$ This, in my view, is the result of the fact that these jurisdictions had to a certain extend replaced France as the dominant force in the legal, economic, political and cultural fields in the Netherlands in this period.

The current legal, economic, political and to a certain extent cultural integration of the Member States of the European Union may serve as a strong impetus for the 'spontaneous' harmonization or, at least, approximation of the civil procedural systems in Europe in the future ${ }^{54}$ An example of spontaneous approximation that may be observed in Europe is the increase in the case management powers of the judge in a large number of European jurisdictions including England (as of 1999), mentioned in the introduction of this paper..$^{55}$ Although this development started at the end of the nineteenth century in Austria, it is not unlikely that European integration is one of the factors that has stimulated its acceptance in a growing number of current EU Member States. After all, especially during the last decades, when European integration became more intense than before, the introduction of case management powers for the judge has occurred at an increasing pace, ${ }^{56}$ especially

50 C H van Rhee, 'The Influence of the French Code de Procédure Civile (1806) in 19th Century Europe' in L Cadiet G Cavinet (eds), De la Commémoration d'un code à lautre: 200 ans de procédure civile en France (Litec 2006) 129-165 ; ; Heirbaut (n 47).

51 Heirbaut (n 47).

$52 \mathrm{C} H$ van Rhee, 'Ons tegenwoordig sukkelproces': Nederlandse opvattingen over de toekomst van het burgerlijk procesrecht rond 1920 (Tijdschrift voor Rechtsgeschiedenis 2000) 331-346.

53 C H van Rhee, 'The Development of Civil Procedural Law in Twentieth-Century Europe: From Party Autonomy to Judicial Case Management and Efficiency' in C $\mathrm{H}$ van Rhee (ed), Judicial Case Management and Efficiency in Civil Litigation (Intersentia 2008).

$54 \mathrm{C} \mathrm{H}$ van Rhee ( $\mathrm{n} 40$ ). The use of the term 'approximation' is based on the title of the Report of the Storme Group, discussed below (M Storme (ed), Approximation of Judiciary Law in the European Union/ Rapprochement du Droit Judiciaire de l'Union européenne (Kluwer, Dordrecht 1994). See now also Art. 81(1) of the Treaty on the Functioning of the European Union.

$55 \mathrm{C}$ H van Rhee (n 53).

56 C H van Rhee (n 53); R Stürner, The Principles of Transnational Civil Procedure: An Introduction to their Basic Conceptions (Rabels Zeitschrift 2005) 226-227. 
in Western Europe. Given the fact that the States of Western Europe have for a long time been in close contact with each other within the framework of the European Community (or the European Free Trade Association), this is in my opinion not a surprise. It is not surprising either that the judge's case management powers are more problematic in the former Eastern Block States that are currently a member of the EU ${ }^{57}$ given their isolation from Western Europe during the Cold War period and their radically different political and economic make-up at that time. This may, however, change over time, not only due to the continuing integration of Europe within the context of the European Union, but also due to the increasing availability of information through the Internet and the important activities of international bodies like the International Association of Procedural Law and the Council of Europe (e.g. the European Commission for the Efficiency of Justice).

The example of spontaneous harmonisation in the area of judicial case management shows that this type of harmonisation is not limited to minor issues in the procedural field, but that it may influence important aspects of the existing civil procedural systems in today's world. After all, the early nineteenth century idea, clearly expressed in the highly influential French Code de procédure civile of 1806, that civil litigation is a private matter and only of interest to the parties to the lawsuit, was originally one of the corner stones of most European legal systems. ${ }^{58}$ According to the French Code, the parties were considered to be free in deciding how they would conduct their case. They could opt for litigating expediently, but could also decide to have their case move forward at a slow pace. Although according to one nineteenth-century observer the French judge had already become rather active at the end of the nineteenth century without the need for specific procedural regulations to this end, ${ }^{59}$ it was only after the necessary theoretical framework had been developed by this very same observer (Franz Klein, 1854-1926) that the new perspective of the judge as case manager became popular, first in Austria and later beyond. ${ }^{60}$

Klein's influence in Europe may be demonstrated by the reception of his theoretical ideas in other European jurisdictions. Klein's aim was the realisation of the socalled 'social function' (Sozialfunktion) of civil litigation. This 'social function' may be viewed as a reaction against the nineteenth century liberal ideal of procedure. It meant that litigation should not only be considered as a means to solve individual lawsuits

57 C H van Rhee, 'Introduction' in C H Van Rhee (ed) European Traditions in Civil Procedure (Intersentia 2005) 23.

58 On the history of the French Code of Civil Procedure, see A Wijffels, 'The Code de procédure civile (1806) in France, Belgium and the Netherlands' in C H van Rhee et al. (eds.), The French Code of Civil Procedure (1806) after 200 years. The Civil Procedure Tradition in France and Abroad (Kluwer 2008) 5-73.

59 Franz Klein (1854-1926) claimed in the 1890s that even though the French Code of Civil Procedure did not grant the French judge far-reaching case management powers, such powers were, in practice, exercised by him without a legal basis in the Code. See Klein (n 42)25: 'Dem französischen Rechte ist der Richter in Prüfen, Glauben und Urtheilen eine lebendige Person mit zu achtenden intellectuellen und moralischen Bedürfnissen, nicht ein blutleerer Judicaturapparat, wie sich ihn das gemeine Recht ausgesonnen hat. Diese so unscheinbare Wahrheit [...] erklärt, warum in Frankreich freie Instructionsthätigkeit des Richters ohne besondere gesetzliche Anerkennung bestehen, die allercursorischste Normirung genügen kann. That claim echoes an observation constantly made by French authors themselves writing on civil procedure from the latter part of the nineteenth century onwards, although of course verifying the veracity of such statements would require extensive research of the French case law and of day-to-day practice during this period.

60 P Oberhammer and T Domej, 'Germany, Switzerland and Austria (ca. 1800-2005)' in C H van Rhee (ed), European Traditions in Civil Procedure (Intersentia 2005) 103-128. 
between private litigants, but also as a phenomenon that affected society as a whole. ${ }^{61}$ Civil procedure should serve the public interest (Wohlfahrtsfunktion), but it had to be viewed from an economic perspective as well. The economic perspective meant that one should, for example, guard against civil procedure being used as a means to postpone payment of a debt or to obtain money at a low interest rate. ${ }^{62}$ As a result, the judge was given the task to make sure that court time was used in the right manner. His case management powers were also needed because the parties were only theoretically equal (the premise of equality lies at the basis of the French Code de procédure civile of 1806). Conducting litigation in an inefficient manner was, for example, usually not the result of a joint decision of the parties, but only of one party who would gain from protracted litigation and who had the money to afford this type of litigation.

The new perspective was adopted in many European States, first only in Germany (especially from the 1920s onwards), ${ }^{63}$ but in the second half of the twentieth century also in many other jurisdictions.

Due to the increasing pace of internationalization and globalization, which results in the legal, economic, political and/or cultural integration of various parts of the world in larger entities, one may expect harmonisation as described in this section to occur on an ever larger scale in the future. After all, internationalization and globalization mean a closer contact between a larger number of States in the legal, political, economic and cultural sphere, and this will result in an ever growing number of relevant foreign procedural models in national law reform projects that adopt a comparative approach, either explicitly or implicitly.

\section{HARMONISATION AS A RESULT OF COMPETITION BETWEEN PROCEDURAL SYSTEMS}

In the present chapter, I will deal with harmonisation of civil procedural law as a sideeffect of the wish to create a competitive forum for civil litigation. Although this may not be the major goal of law reformers in today's world, this may change in the future for reasons stated below. Before we look at the future, however, I would like to have a look at the past and summarise the success story of the medieval Romano-canonical procedure that lies at the basis of the various systems of civil procedural law on the European Continent. ${ }^{64}$ In my opinion, competition between procedural systems in the medieval world explains this success and, consequently, it is a good example of harmonisation of procedural models as a side-effect of competition.

$61 \quad$ Klein asked the following rhetorical question: 'Sollte das "Processeigenthum" stärker als alles sonstige Privateigenthum sein, und muss erst gesagt werden, welches die öffentlichen Interessen sind, mit denen die uns so selbstverständliche schrankenlose Disposition über den Processinhalt collidirt, und was sich dann gerade aus der Eigenthumsanalogie ergibt?' (Klein n 42 17).

62 See H W Fasching, 'Die Weiterentwicklung des österreichischen Zivilprozessrechts im Lichte der Ideen Franz Kleins' in Hofmeister (ed), Forschungsband Franz Klein (1854-1926). Leben und Wirken (Manz 1988) 97-117, and Van Caenegem (n 32) 97.

63 G Walter, 'The German Civil Reform Act 2002: Much Ado About Nothing?' in Trockner and Varano (eds), The Reforms of Civil Procedure in Comparative Perspective (Giappichelli Editore 2005) 67-72.

64 For more detailed information, see $\mathrm{C} \mathrm{H}$ van Rhee, Civil Procedure: A European Ius Commune? (2010) 8 (4) European Review of Private Law 2000 589-611. 
The Romano-canonical procedure was developed within the context of the medieval Church and its spread to secular courts can - at least in part - be explained on the basis of its attractiveness for the litigants. Much earlier than medieval secular courts, medieval ecclesiastical courts knew a written procedure which aimed at uncovering the substantive truth by way of a rational system of proof. This system of proof did not appeal to supra-natural forces - as the old system did, for example by way of ordeals such as trial by battle - but was based on means of proof that are still recognized in our modern procedural systems: the emphasis was on documents, but, for example, the examination of witnesses also started to play an important role. This increased the predictability of the outcome of cases and, as a result, many litigants tended to prefer litigation before a church court instead of litigation before a secular jurisdiction. In areas and cases where a choice of forum was possible, this was detrimental to worldly rulers in various ways, for example from the perspective of their prestige and influence, but also as regards the revenues related to court litigation. Since a choice of forum was more often possible in the medieval world than today due to overlapping jurisdictions and the absence of clear-cut jurisdictional rules, high numbers of litigants started to flock to the ecclesiastical courts quickly after the introduction of the new procedure there. As a result, the secular courts lost a considerable amount of business, and it has been held that this is one of the reasons why they started to adopt elements of the Romano-canonical procedure, first of all the superior secular courts. After all, they needed to strengthen their position in respect of the ecclesiastical courts. They did not chose for a wholesale adoption of the new procedure, however, since each secular court knew its own mix of Romanocanonical and indigenous elements. Nevertheless, this mixing must have served its purpose since as a result the secular courts in the various parts of Europe were able to increase their success vis-à-vis the church courts. At the same time it resulted in a certain approximation of the procedural models of the various European courts.

In our modern world and especially in a national context, competition between courts on the basis of procedural rules has virtually disappeared. This is due to the introduction in most States of nation-wide uniform procedural models for the courts. Nevertheless, this does not mean that the State courts do not have to fear any competition at all. After all, although litigants cannot influence the procedural law applied by the State courts and therefore have to accept the national procedural models when litigating at these courts, they can in various cases decide to avoid litigation at these courts all together by choosing arbitration or other types of ADR, or opt for the court of a foreign State by way of a choice of forum. In this way, they indirectly chose the applicable rules of procedural law and, in a study by Vogenauer and Hodges, ${ }^{65}$ it is shown that as regards choices of forum the procedural law applied by the forum is one of the factors that is taken into consideration by businesses. ${ }^{66}$ States who consider it important to attract international litigation will - or at least should - therefore consider whether their procedural law - either positively or negatively - affects a choice of forum. Comparative civil procedure is relevant

65 S Vogenauer and C Hodges (eds), Civil Justice Systems in Europe: Implications for Choice of Forum and Choice of Contract Law (Hart Publishing 2011).

Vogenauer and Hodges (n 65). 
for these States because comparing a national procedural model with foreign procedural regimes is indispensable in order to evaluate the strengths and weaknesses of a particular procedural system in an international context. ${ }^{67}$ Such comparative research may, of course, result in a certain approximation since it may give rise to the adoption of successful procedural rules and models from abroad.

States may be interested in attracting litigation for various reasons. One reason might be that they want cases that are in one way or another linked to their own jurisdiction litigated before their national courts. Another reason might be related to attracting businesses. A preference by the international business community for the courts of a particular State may be held to indicate that this community regards this State as an attractive place, not only from the perspective of litigation, but also from the perspective of doing business. ${ }^{68}$ Most likely, businesses that choose the forum of a particular State trust the proper functioning of the organs of that State in general, i.e. not only that of the courts. Another reason for a State's interest in attracting international litigation is that such litigation may be an incentive for the development of the national legal services market, or for the development of case law for a large number of situations, and there may be many other reasons.

One step States may take in improving their competitiveness in the international litigation market is to change their rules of procedure, both for domestic cases and for international litigation. However, this is a very drastic step which - apart from its unpopularity ${ }^{69}$ - may not be effective, since different litigants may have different preferences. Another approach is introducing some flexibility in the application of procedural rules, allowing litigants a certain choice in the applicable procedural regime, for example by allowing them to opt for the application of alternative - domestic or foreign - procedural rules as regards certain aspects of their case or packages of such rules. Especially offering a limited number of packages of rules (i.e. procedural models) at the national level is, in my opinion, an interesting option, since a choice of individual rules may result in an unworkable situation due to the high number of combinations of rules that are available, and also because it may result in a choice that is only beneficial for the economically stronger party while being detrimental to his opponent. Additionally, offering packages allows the national legislator to achieve certain policy aims, e.g. by offering combinations that are at the same time attractive to international litigants and beneficial from the perspective of these policy aims. Rules allowing the judge to be an active case manager could, for

67 In a European context, the various reports of the European Commission for the Efficiency of Justice (CEPEJ) are of interest <www.coe.int/en/web/cepej/> accessed 1 November 2018). See P Albers, 'Judicial Systems in Europe Compared' in Van Rhee and Uzelac (eds), Civil Justice between Efficiency and Quality: From Ius Commune to the CEPEJ (Intersentia 2008) 9-28. See also P Albers, 'Quality Assessment of Courts and the Judiciary: From Judicial Quality to Court Excellence' in A Uzelac and C H Van Rhee (eds), Access to Justice and Judiciary: Towards New European Standards of Affordability, Quality and Efficiency of Civil Adjudication (Intersentia 2009) 57-74.

68 In this respect the Doing Business Reports of the World Bank are of interest. Part of the comparison made by the World Bank concerns the national justice systems of the various economies. See $<$ www.doingbusiness.org/> accessed 1 November 2018).

69 E.g. G Walter and S Baumgartner, 'Utility and Feasibility of Transnational Rules of Civil Procedure: Some German and Swiss Reactions to the Hazard-Taruffo Project' (1998) Texas International Law Journal 463-476. 
example, be combined with extended discovery mechanisms in order to cater for both the international litigant who wants an efficient administration of justice and for national policy makers aiming at litigation based on the substantive truth as opposed to the truth as fabricated by the parties.

It may even be possible to allow the parties a certain flexibility as regards the choice of some of the rules that are offered within each package. Allowing a choice of the applicable procedural rules (e.g. domestic or foreign rules or rules based on the ALI/Unidroit Principles of Transnational Civil Procedure) within the various packages might not be as problematic as it may seem, since not all procedural rules are closely related to the overall procedural model of a country, to the system of substantive private law or have, e.g., constitutional significance. An example is the rules on the computation of time, but also various rules as regards conciliation, the commencement of the proceedings and the subject-matter of the litigation..$^{70}$ In my opinion, a distinction should be made between rules that are either closely related to substantive law or the procedural system, or that have constitutional significance - such as those concerning the available means of recourse against judgments which impact on judicial organization, i.e. a constitutional issue - and rules that can be viewed in isolation and that do not have such significance. It is unlikely that States would be willing to subject the former procedural rules to the parties' preferences. However, the story may be different regarding the latter rules.

An early example of a trend towards flexibility as regards procedural rules may be witnessed in the Nordic countries. According to Laura Ervo, in these countries ' $t$ ] he state delegates more and more disposition power to the parties concerning matters of action.' Based on the writings of P.H. Lindblom, she observes that '[i]n Sweden, parties already have quite a lot of power to decide procedural matters and, for instance, the possibility to choose written or oral preparation to some extent.' It is held by this author that the dominating trend in Swedish civil procedure is expanding flexibility and the same kind of large freedom on procedural forms has according to her been suggested for Finland. The author states that this freedom is viewed as positive for the competitiveness of courts. ${ }^{71}$

\section{INTENDED HARMONISATION ${ }^{72}$}

One of the major reasons for the recent growth of interest in comparative civil procedure are attempts to harmonize civil procedural law in various parts of the world or even on a global scale. Two such harmonization attempts that are invariably mentioned in comparative procedural studies are the Storme Report ${ }^{73}$ and the Principles

70 See, e.g., the various proposals for harmonisation in M Storme (ed), Approximation of Judiciary Law in the European Union/ Rapprochement du Droit Judiciaire de l'Union européenne (Kluwer, Dordrecht 1994).

71 L Ervo, 'Party Autonomy and Access to Justice' in Ervo, Gräns and Jokela (eds), Europeanization of Procedural Law and the New Challenges to Fair Trial (Europa Law Publishing 2009) 26.

72 This chapter is based on parts of $\mathrm{C} \mathrm{H}$ van Rhee, 'Civil Procedure in a Globalizing World: A Historical Perspective' in Faure and Van der Walt (eds), Globalization and Private Law: The Way Forward (Edward Elgar 2010) 343-367.

73 M Storme (ed), Approximation of Judiciary Law in the European Union/ Rapprochement du Droit Judiciaire de l'Union européenne (Kluwer, Dordrecht 1994). 
of Transnational Civil Procedure of the American Law Institute and Unidroit. ${ }^{74}$ The Storme Report is the result of such a development on a European scale, whereas the Transnational Principles are the result of a similar development in the area of commercial disputes on a world-wide scale. Currently, there is a third project, i.e. the project aiming at Rules of European Civil Procedure within the context of the European law Institute and Unidroit. Early results of this project are expected later this year (2019).

\subsection{Harmonization on a European scale}

Harmonization and even unification of civil procedural law may be required for various reasons. Although litigants may, in several cases, opt for a court with their preferred procedural regime, this is not always possible. Apart from legislation prescribing the litigants to conduct their lawsuit before the courts of a specific jurisdiction (e.g., where the case concerns immovable property), a choice of forum may not be feasible for financial reasons. In an economic area as the European Union, this may create problems from the perspective of the four freedoms (free movement of persons, goods, capital and services). Citizens may, for example, decide to abstain from purchasing certain goods outside their own jurisdiction because of (perceived) problems when litigation should become necessary. Additionally, businesses may be influenced by differences in procedural law in deciding to produce and market products in the various Member States. Although the impact of differences in procedural law in this particular area may be limited, they nevertheless contribute to a fragmented market and not to the creation of the single internal market that is the objective of European cooperation. ${ }^{75}$ Additionally, the result of this is differences as regards access to justice which, within the context of the European Union- or the wider context of the Council of Europe may be considered undesirable. ${ }^{76}$

To start with the Council of Europe: due to Article 6 of the European Convention on Human Rights (ECHR) (which is comparable to Article 14 International Convenant on Civil and Political Rights and Article 47 of the Charter of Fundamental Rights of the European Union) and especially the case law of the European Court of Human Rights, Member States of the Council must guarantee the observance of some fundamental procedural guarantees, in the area of both criminal and civil litigation (obviously, I will only discuss civil litigation here). The case law of the European Court of Human Rights on Article 6 has been instrumental in laying down the minimum requirements each national procedural regime of the Member States should meet. On the basis of this case law, it has appeared that Article 6 prescribes the following guarantees: ${ }^{77}$

74 ALI/UNIDROIT, Principles of Transnational Civil Procedure (Cambridge University Press 2006). Another example is the Código Procesal Civil Modelo para Iberoamérica (1994). The text may be found at the website of the 'Centro de Estudios de Justicia de las Americas' < http://cejamericas. org/>, accessed 1 November 2018. I will not discuss various initiatives as regards Arbitration and the Hague Conventions on civil procedure in the present paper.

75 See Arts $26 \mathrm{ff}$ Treaty on the Functioning of the European Union.

76 E Storskrubb, Civil Procedure and EU Law. A Policy Area Uncovered (Oxford University Press 2008) 1-3, 78.

77 See also Andrews (n 34) 54-55. 


\section{Access to justice ${ }^{78}$}

2. A fair hearing (trial), which includes: ${ }^{79}$

a. the right to adversarial proceedings;

b. the right to equality of arms;

c. the right to be present at the trial;

d. the right to an oral hearing

e. the right to a fair presentation of evidence;

f. the right to a reasoned judgment;

3. A public hearing, including the public pronouncement of judgment;

4. A hearing within a reasonable time;

5. A hearing before an independent and impartial tribunal established by law.

Although Article 6 does not necessarily lead to unification as regards procedural rules sensu stricto, some 'approximating' effects of the fundamental principles of Article 6 have been witnessed during the last decades, for example as regards legal aid or other measures increasing access to justice, the reasonable time requirement, the rise of the oral element in civil litigation and the admissibility of the parties as witnesses..$^{80}$ These effects are also important within the context of the European Union, since all Member States are a party to the ECHR and because Article 6 ECHR and the case law based on it are part of the acquis communautaire ${ }^{81}$ something which is also reflected by Article 47 of the Charter of Fundamental Rights of the European Union. ${ }^{82}$

Even though Article 6 ECHR has had an approximating effect, this is not necessarily the aim of this Article: it only aims at laying down some fundamental guarantees. In actual fact, the need for harmonization for a group of 47 European countries ${ }^{83}$ that are rather diverse may not be felt as urgently as within the context of an entity such as the European Union. This is not surprising, taking into consideration that even within the European Union harmonization of procedural law is a controversial issue. In actual fact, apart from the fundamental procedural principles of Article 6 ECHR that should be observed in all Member States, the harmonization that has been achieved in the European Union is rather limited and expressly focused on international cases, leaving purely national cases often outside the discussion (see below).

Within the context of the European Union, Article 81 of the Treaty on the Functioning of the European Union (former Article 65 of the Treaty Establishing the

78 Golder v. UK, 4451/70, judgment of 21 February 1975.

79 P van Dijk et al, Theory and Practice of the European Convention on Human Rights (Intersentia 2006) 578-596.

80 M Freudenthal, Schets van het Europees civiel procesrecht (Kluwer 2007) 269-270.

81 I.e. the total body of European Union law accumulated this far.

82 Art 6(2) Treaty on European Union (TEU); Charter of Fundamental Rights of the European Union (Official Journal C 364, 18/12/2000, 1-22), Art 47: Everyone whose rights and freedoms guaranteed by the law of the Union are violated has the right to an effective remedy before a tribunal in compliance with the conditions laid down in this Article. Everyone is entitled to a fair and public hearing within a reasonable time by an independent and impartial tribunal previously established by law. Everyone shall have the possibility of being advised, defended and represented. Legal aid shall be made available to those who lack sufficient resources in so far as such aid is necessary to ensure effective access to justice.

Nearly all European countries are a member of the Council of Europe, with the exception of the Vatican, and of Belarus because of this country's lack of respect for human rights and democratic principles. 
European Community) ${ }^{84}$ introduced by the Treaty of Lisbon in 2009, is of utmost importance from a civil procedural point of view. It states that:

1. The Union shall develop judicial cooperation in civil matters having crossborder implications, based on the principle of mutual recognition of judgments and of decisions in extrajudicial cases. Such cooperation may include the adoption of measures for the approximation of the laws and regulations of the Member States.

2. For the purposes of paragraph 1, the European Parliament and the Council, acting in accordance with the ordinary legislative procedure, shall adopt measures, particularly when necessary for the proper functioning of the internal market, aimed at ensuring:

(a) the mutual recognition and enforcement between Member States of judgments and of decisions in extrajudicial cases;

(b) the cross-border service of judicial and extrajudicial documents;

(c) the compatibility of the rules applicable in the Member States concerning conflict of laws and of jurisdiction;

(d) cooperation in the taking of evidence;

(e) effective access to justice;

(f) the elimination of obstacles to the proper functioning of civil proceedings, if necessary by promoting the compatibility of the rules on civil procedure applicable in the Member States;

(g) the development of alternative methods of dispute settlement;

(h) support for the training of the judiciary and judicial staff.

\section{3. [family law]}

Many of the fields mentioned in this Article have already resulted in European legislation $^{85}$ (applicable to all Member States, usually with the exception of Denmark), by way of either Regulations or Directives.$^{86}$ As stated, however, the harmonization

84 Former Article 65 European Community Treaty: Measures in the field of judicial cooperation in civil matters having cross-border implications, to be taken in accordance with Article 67 [Article 67 ECT lays down the procedure for the adoption of legislation under, amongst other Articles, Article 65. See Storskrubb (n 76) 47-48] and in so far as necessary for the proper functioning of the internal market, shall include:

(a) improving and simplifying:

- the system for cross-border service of judicial and extrajudicial documents,

- cooperation in the taking of evidence,

- the recognition and enforcement of decisions in civil and commercial cases, including decisions in extrajudicial cases;

(b) promoting the compatibility of the rules applicable in the Member States concerning the conflict of laws and of jurisdiction;

(c) eliminating obstacles to the good functioning of civil proceedings, if necessary by promoting the compatibility of the rules on civil procedure applicable in the Member States.

85 I will not discuss the European Judicial Network here, nor judicial training and some other measures. See Storskrubb (n 76) $233 \mathrm{ff}$.

86 For non-European lawyers, it may be useful to know that a Regulation is a legislative act which becomes immediately enforceable as law in all Member States simultaneously. Regulations can be distinguished from Directives, which need to be transposed into national law by the Member States. Directives may give rise to different national legislative solutions in order to reach the aim 
resulting from these instruments only concerns international cases. This means that purely national cases continue to be governed by the rules of civil procedure of the Member State where the case is brought. In my opinion, this is unfortunate, especially since it would have been possible to interpret Article 81(2)f (former Article 65 sub c ECT) broadly, in the sense that it may form the basis of an alignment of the civil procedural laws of the Member States irrespective of the national or international character of litigation. After all, it could be claimed that differences between the procedural laws of the Member States always have cross-border implications, e.g. in the sense that businesses may be affected by these differences when deciding where to produce and market their products. The free movement of persons, goods, services and capital within the EU and, consequently, the proper functioning of the internal market are affected by a restrictive interpretation. In my opinion, the differences in civil procedural law can often only be removed by Union action and not by action at the respective national levels and, consequently, the principle of subsidiarity of Article 5 Treaty on European Union (former Article 5 ECT) does not prevent the Union from using its powers. Also, the principle of proportionality mentioned in the same Article 5 does not seem to hinder Union action. Nevertheless, this interpretation of Article 81 TEU is currently politically unacceptable for the Member States. ${ }^{87}$

Although the European approach excludes purely national cases, a debate on the 'approximation' of the national procedural laws of the Member States of the European Community was launched already in the late 1980s, i.e. before the introduction of Article 81 and its predecessor, Article 65 ECT. As is widely known, the initiative was taken by a working group chaired by Professor Marcel Storme from Ghent (Belgium). The report this working group produced does not distinguish between national and international cases and was aimed at the then 12 Member States of the European Community.

In his introduction to the Report, Professor Storme states that harmonization of civil procedural law is more feasible than harmonization of other fields of law. The author claims that this is the result, amongst other things, of the fact that in the area of procedure many of the rules are not interrelated with other rules, either procedural or substantive ${ }^{88}$ (apart from some procedural rules which are, e.g., closely interwoven with substantive law, such as those concerning marriage and divorce, areas for which the current Article 81(3) of the Treaty on the Functioning of the European Union contains specific provisions). ${ }^{89}$ Consequently, an immediate overall overhaul of the system is not needed and harmonization may proceed on a piecemeal basis..$^{90}$

of the Directive. All Regulations and Directives mentioned in this paper can be found on the website of the European Union: <http://europa.eu/> (accessed 2 October 2018).

87 Storskrubb(n 76) 39, 272-273. The European Small Claims Procedure, for example, was originally envisaged as also being applicable in purely national disputes. At a late moment in the drafting process, however, it was decided that it would only cover international cases, leading to a discrimination as regards purely domestic cases in jurisdictions where the national rules are less favorable than the European rules. See Storskrubb (n 76) 220-221.

88 Storme (n 73) $53 \mathrm{fff}$.

89 Storme (n 73) 57-58.

$90 \quad$ Storme (n 73) 54. 
The original idea of the Storme Group was to produce a model code, to be implemented by way of a Directive. ${ }^{91}$ However, it was soon realized that there were still too many differences between the procedural systems of the 12 Member States to make a generally acceptable, all-encompassing proposal possible. Therefore, the Working Group concentrated on 16 separate issues which, in their view, were fit for approximation: (1) Conciliation, (2) Commencement of the Proceedings, (3) Subject matter of litigation (pleadings, i.e. statements of case), (4) Discovery, (5) Witnesses, (6) Technology and Proof, (7) Discontinuance, (8) Default, (9) Costs, (10) Provisional Remedies, (11) Order for Payment, (12) Enforcement, (13) Astreinte, (14) Computation of time, (15) Nullities and (16) some general rules concerning judges and judgments (appeal and disqualification of judgments). In the Report, the rules as regards some of these issues are very detailed (e.g. commencement of the proceedings), whereas other issues are regulated in a rather sketchy manner (e.g. witnesses). Although the rules themselves are available in both French and English, the accompanying explanatory memorandum, comments and recitals are only available in either French or English (depending on the language skills of the person responsible for a certain part of the memorandum or the other documents), which is due to the limited means available to the Working Group. ${ }^{92}$

Criticism was soon to come. To mention but one example, in the European Review of Private Law, Professor Per Henrik Lindblom discussed various issues which in his opinion showed the weaknesses of the Storme report. ${ }^{93} \mathrm{He}$ claimed that the report did not make clear whether it meant to lay down only minimum requirements or standard rules. ${ }^{94}$ Professor Lindblom stated that if the report was meant to formulate standard rules, it might not give rise to an improvement in countries that have higher quality rules. ${ }^{95}$ At the same time, the author held that if only minimum rules were given, it might be questioned whether this would lead to harmonization or approximation. ${ }^{96}$ Additionally, Professor Lindblom observed that several of the rules suggested by the Report were rather general and often did not address the real problems in the area of civil procedural law. He demonstrated this, amongst other things, by mentioning that the Report contains only one article (Article 5) concerning witnesses, an article which in his view states the obvious, since it only lays down that '[a]ny person duly summoned in accordance with the law of a Member State to give evidence before a court of that State shall be under a duty to appear before that court and give evidence.97

Although the criticism may be justified, the significance of this first attempt to provide a model for the approximation of procedural law in the European Union, involving the leading experts in the field at the time, should in my perspective not be underestimated. ${ }^{98}$ One of its achievements is that it has triggered the debate on the pos-

\footnotetext{
91 Storme (n 73) 61 For a definition of a Directive, see footnote 55.

92 Storme (n 73) 62-63.

93 Lindblom (n 38).

94 Lindblom (n 38) 32, 45.

95 Lindblom (n 38), 45.

96 Lindblom (n 38) 32.

97 Lindblom (n 38) 36.

98 For some very derogative remarks, see e.g. A Biondi, 'Minimum, Adequate or Excessive Protection? The Impact of EC Law on National Procedural Law' in Trockner and Varano (eds), The Reforms of
} 
sibility and the pros and cons of procedural harmonisation and has been a source of inspiration for other projects, notably a project initiated by the American Law Institute and later also sponsored by Unidroit, i.e. the Principles of Transnational Civil Procedure, ${ }^{99}$ and later the European Rules of Civil Procedure mentioned above (and about which later).

\subsection{Harmonization on a world-wide scale: The Principles of Transnational Civil Procedure}

In the comparative study of civil procedure, the Principles of Transnational Civil Procedure are of considerable importance. According to one author, disregarding the Principles 'might be declared a form of procedural illiteracy.' ${ }^{100}$ They are a major achievement, considering that the majority of comparatists are of the opinion that harmonization of civil procedure on a world-wide scale was not possible. ${ }^{101}$ As was to be expected, the project met with fierce criticism, especially in the initial stages. The most amusing book in this respect is in my opinion a volume edited by Philippe Fouchard, Vers un procès civil universel. Les règles transnationales de procédure civile de l'American Law Institute (Paris, Panthéon-Assas 2001), where various French authors show themselves in a rather parochial manner, to put it mildly.

The initiators of the project, Geoffrey Hazard Jr. and Michele Taruffo, originally intended to draft a code of rules for national courts that would set aside domestic procedural rules: (1) when litigation between parties from different States would take place or (2) whenever property in one State would be the object of litigation by a party from another country. These rules would form a code acceptable both from the Common Law and the Civil Law perspective. ${ }^{102}$ In 1997 the American Law Institute adopted the project ${ }^{103}$ and in 2000 Unidroit joined. ${ }^{104}$ This gave rise to a change,

Civil Procedure in Comparative Perspective (Giappichelli Editore 2005) 233: 'The rather ponderous project (127 articles!), as it is otherwise known, was soon pilloried (complex, adding complexity to quote the kindest) and did not produce any practical effects. Its lasting notoriety is due to the fact that it is invariably quoted in any articles that deal with procedural law and European law. It should, however, be remembered that complexity (meaning a large number of articles) is not felt by everyone as a negative aspect of procedural legislation, taking into consideration the contribution in the same volume of Díez-Picazo Giménez, entitled 'The Principal Innovations of Spain's Recent Civil Procure Reform' (33-66), who highly praises the new Spanish Code of Civil Procedure. On the basis of his contribution, however, the least that can be said about this new Code is that it is complex (it contains 827 articles although it does not even cover many of the areas which in other Civil Law countries are usually part of the Code of Civil Procedure) and, according to the author, in various instances unclear. Sometimes the so-called 'innovations' of this new code are even medieval in character. The following quote is rather interesting for someone with some knowledge of the history of civil procedure: 'A special device has been established [by the new code] for issues related to jurisdiction and proper venue of the court: the so called declinatory plea (declinatoria) ... Exceptions of lack of jurisdiction and proper venue have to be raised by the defendant prior to filing his answer ... It suffices to know that the declinatory plea already figures in the $13^{\text {th }}$ century Speculum Iudiciale of Durantis.

ALI/UNIDROIT (n 74) 3. See for an extensive bibliography on the Principles: ALI/UNIDROIT (n 74) $157 \mathrm{ff}$.

100 Andrews (n 34) 52.

101 R Stürner, The Principles of Transnational Civil Procedure: An Introduction to their Basic Conceptions (Rabels Zeitschrift 2005) 203.

102 Stürner (n 101) 204.

103 ALI/UNIDROIT (n 74) xxxi.

104 ALI/UNIDROIT (n 74) 4. 
since Unidroit did not feel that civil procedure rules of some detail would be acceptable to different cultures. It was of the opinion that it was better to develop a set of general Principles ${ }^{105}$ Finally, only the Principles were adopted by the American Law Institute and Unidroit, although it was felt that the rules represent a possible example of implementation of the Principles. ${ }^{106}$

The final draft of the Principles of Transnational Civil Procedure dates from 2004. It was published in 2006 by Cambridge University Press in English and French. ${ }^{107}$ The publication also includes a commentary.

According to their drafters, the Principles must be seen as best practices and a benchmark for national procedures. ${ }^{108}$ Consequently, they are not necessarily only aimed at international cases, but may also be used within a national context, e.g. in national reform projects (see below). They are a blend of elements from the Civil Law and the Common Law: ${ }^{109}$ discovery is, for example, limited in nature, ${ }^{110}$ but this is corrected by a liberal approach towards shifting the burden of proof. ${ }^{111}$ Additionally, the hearing of the case is concentrated, but this does not necessarily mean that there should only be a single trial. ${ }^{12}$ The hybrid character of the Principles may also be viewed slightly less favourably. According to Neil Andrews, '[e]verywhere the restraining hand of the Civil Law is visible and robust Common Law tendencies are curbed."13

The Principles aim in the first place at transnational commercial litigation. ${ }^{114}$ This approach was adopted in order to increase the chances that the Principles would be acceptable to lawyers from various jurisdictions. After all, in commercial litigation there is no jury and the existence of the jury in civil cases is a major issue separating the US from most other jurisdictions. By only focusing on commercial litigation, the whole subject of the jury could be excluded from consideration. ${ }^{115}$ Additionally, it was felt that international commercial litigation is less subject to national legal traditions than other types of litigation because the existence of a body of welldeveloped rules of commercial arbitration offered a good common starting point. ${ }^{116}$

Apart from transnational commercial litigation being a field where harmonization is feasible, there are also intrinsic reasons for concentrating on this area. In the introduction to the Principles we find the following comment: 'The explosion in transnational commerce has changed the world forever. International commerce and investment

\footnotetext{
105 Stürner (n 101) 205-206. On the three types of Principles that may be distinguished, see Storskrubb (n 76) 290.

106 ALI/UNIDROIT (n 74) 4; Stürner (n 101) 205-209, 215.

107 ALI/UNIDROIT (n 74) 9.

108 ALI/UNIDROIT (n 74) xxix.

109 ALI/UNIDROIT (n 74) 11.

110 ALI/UNIDROIT (n 74) Principle 16.

111 ALI/UNIDROIT (n 74) Principle 21.

112 ALI/UNIDROIT (n 74) Principle 9.

113 Andrews (n 34) 53.

114 ALI/UNIDROIT (n 74) 'Scope and Implementation', 16. The terms 'transnational' and 'commercial' are not defined precisely. See ALI/UNIDROIT ( $\mathrm{n} 74$ ), Comment P-B and P-C.

115 ALI/UNIDROIT (n 74) xxvii; Stürner (n 101) 209-210.

116 Stürner (n 101) 210.
} 
are increasing at an enormous rate and the rate of change is continuing to accelerate. The legal procedures applicable to the global community, however, have not kept pace and are still largely confined to and limited by individual national jurisdictions."117 Consequently, there is a need for initiatives in this area, since the current situation is said to diminish international trade and investment. In the opinion of the drafters, the existing international conventions (Hague Conventions) on civil procedure and related topics are not an answer to the problems, since they only address aspects of civil litigation (e.g. commencement and recognition) and say little about the actual procedure to be followed. ${ }^{118}$ From this perspective, they may also be highly relevant from an European Union perspective, as many of the existing European Regulations on civil procedure show the same limitations as the Hague Conventions (see above).

Even though the Principles aim at transnational commercial litigation, this does not mean that they are without use in other fields. On the contrary, they may, for example, (1) influence the further development of the rules of national and international arbitration (to which they are themselves indebted), ${ }^{119}$ (2) be used by national law reformers as an example of world-wide accepted guidelines and standards of procedural law, ${ }^{120}$ and (3) be consulted by national judges in the interpretation of national procedural rules and international conventions that are formulated in a way which leaves the necessary room for judicial interpretation. ${ }^{121}$ Finally, (4) they may be used as standards against which foreign judgments and arbitral awards may be measured when a decision has to be taken as regards their recognition and enforcement. ${ }^{122}$ The use of the Principles under (2) and (3) may give rise to spontaneous harmonisation or harmonisation as a side-effect as mentioned above.

The procedural model suggested by the Principles aims to avoid favouring national parties in international litigation. ${ }^{123}$ It is a flexible model, which accommodates all of the existing national procedural models. Nevertheless, the Principles suggest a preferred model. ${ }^{124}$ This model consists of three stages: the pleading stage (statements of case), an interim stage (scheduling) and a final stage (main hearing). ${ }^{125}$ This model is popular in many European countries such as Germany, England and Spain. Stürner calls it the 'main hearing model.' ${ }^{126}$ The Principles assume an active judge ${ }^{127}$ and in this respect they take the German-Austrian model as an example (see above). ${ }^{128}$ This active stance of the judge means that the court is also responsible for determin-

117 ALI/UNIDROIT (n 74) xxix.

118 G C Hazard et al, 'Introduction to the Principles and Rules of Transnational Civil Procedure' (2001) 769 New York University Journal of Law and Politics 770-771.

119 ALI/UNIDROIT (n 74) 10-12. See also ALI/UNIDROIT (n 74) Comment P-E.

120 ALI/UNIDROIT (n 74) 10-11; Idem, 'Scope and Implementation', 16.

121 ALI/UNIDROIT (n 74) 4.

122 ALI/UNIDROIT (n 74) Comment P-A, 16; Stürner (n 101) $210 \mathrm{ff}$.

123 ALI/UNIDROIT (n 74) 1-4.

124 Stürner (n 101) 223, 226.

125 ALI/UNIDROIT (n 74) Principle 9.

126 Stürner (n 101) 224-226.

127 ALI/UNIDROIT (n 74) Principle 14.

128 Stürner (n 101) 226-227. 
ing issues of law, including foreign law. ${ }^{129}$ On the other hand, the Principles lay down that the court is never permitted to introduce new facts not previously advanced or at least briefly mentioned by the parties to litigation. ${ }^{130}$ It is, however, again the court's responsibility to ensure that justice is administered promptly, ${ }^{131}$ a responsibility that is to some extent shared with the parties. ${ }^{132}$ There is no notice pleading like in the US, which means that the assertion of detailed facts and the submission of exactly specified means of evidence during the pleading phase is required. ${ }^{133}$ All contentions of the parties should be considered by the court. ${ }^{134}$ The principle of finality is adhered to. ${ }^{135}$ The Principles do not follow the American rule as regards costs, i.e. they do not follow the rule that each party pays his own expenses. ${ }^{136}$ However, they do recognise the amicus curiae. ${ }^{137}$ Appeal is not a new hearing, but limited to re-evaluating the judgment of first instance. ${ }^{138}$ The Principles discuss sanctions on parties, lawyers and third persons for failure or refusal to comply with the obligations concerning the proceeding. ${ }^{139}$

According to Neil Andrews, several issues are not (sufficiently) addressed by the Principles. The author mentions (1) pre-action co-ordination of exchanges between the potential litigants (pre-action protocols as known in England since the Woolf reforms) and (2) multi-party litigation. Andrews also states that greater attention could be given to the interplay of mediation and litigation, costs and funding, evidential privileges and immunities and transnational and protective relief. ${ }^{140}$ For these and other reasons, the Principles should not be seen as the final stage in the development of procedural harmonization on a global scale, but as an initiative which will certainly witness various follow-ups in the years to come. One of these follow-ups is the European Rules of Civil Procedure of the European Law Institute and Unidroit, which I will briefly introduce in the next section.

\subsection{The ELI/Unidroit European Rules of Civil Procedure}

As stated, the project on European Rules of Civil Procedure is one of the latest initiatives in the field of the intended harmonization of civil procedure. The idea is to develop soft law that may be instrumental in law reform in the Member States of the European Union. The aim is to provide rules based on best practices within the European Union, and in this respect the initiative differs considerably from the Storme Project, which only tried to make an inventory of rules that would be acceptable in all of the then twelve Member States of the European Union. The following topics are addressed: (1) Service and Due Notice of Proceedings; (2) Provisional and Protective Measures; (3) Access to

\footnotetext{
129 Stürner (n 101), 228.

130 ALI/UNIDROIT (n 74) Principle 10; Stürner (n 101) 229.

131 ALI/UNIDROIT (n 74) Principle 7.1; Stürner (n 101) 227.

132 ALI/UNIDROIT (n 74) Principle 11.2.

133 ALI/UNIDROIT (n 74) Principle 11.3; (n 101) 233.

134 ALI/UNIDROIT (n 74) Principle 22.

135 ALI/UNIDROIT (n 74) Principle 26.

136 ALI/UNIDROIT (n 74) Principle 25; Stürner (n 101) 251.

137 ALI/UNIDROIT (n 74) Principle 13.

138 ALI/UNIDROIT (n 74) Principle 27.

139 ALI/UNIDROIT (n 74) Principle 17.

140 Andrews (n 34) 57.
} 
Information and Evidence; (4) Res Judicata and Lis Pendens; (5) Obligations of Parties, Lawyers and Judges; (6) Costs; (7) Judgments; and (8) Parties. Currently, an overarching working group on structure is bringing together the various rules that have been developed under the above 8 headings in order to present a coherent and consolidated set of rules. These rules will most likely become available later this year (2019). ${ }^{141}$

\section{FINAL REMARKS}

Attempts to harmonise civil procedure have made the study of comparative civil procedure (including the history of this area of the law) an exciting field of study during the last few decades. Although the comparative study of civil procedure was originally the domain of national law reformers, busy with drafting new or amended codes of civil procedure in a national context, mainly focusing on nearby jurisdictions, globalisation has made it a field of study for a wider audience. It is a promising area of study, for example where national procedural systems are seen to compete with each other for litigation business. Comparative civil procedure allows these systems to evaluate their strengths and weaknesses in the international playing field when taking into consideration the preferences of litigants who have become ever more mobile where it concerns choices of forum. As has been stated in this paper, especially businesses have certain preferences as regards the procedural model for litigation, to which jurisdictions who aim at attracting litigation before their various state courts should be aware. Additionally, attempts to approximate civil procedural law in an international context benefit tremendously from this field of study. Although successes in this field are limited, especially the Principles of Transnational Civil Procedure of the American Law Institute and Unidroit and the European Rules of Civil Procedure of the European law Institute and Unidroit show us the way ahead. Parochial criticism in this field is of course possible, but as in other areas in today's world, it will quickly become apparent that parochialism is not the way ahead to survive in our modern times in which the world is becoming smaller and smaller. It is to be hoped that the Transnational Principles and the European Rules will trigger further in-depth studies of civil procedure, and I am convinced that in this particular area the study of comparative law, including the study of the history of civil procedure, will continue to add new insights and show the way ahead. In this respect, the comparative study of civil procedure in action could be further developed, whereas the relationship between civil procedure and (procedural) culture and the extent to which procedural reform is implicitly influenced by foreign procedural models should be focused on.

November 3, 2018

141 For more information, see $<$ https://europeanlawinstitute.eu/projects-publications/current-projectsfeasibility-studies-and-other-activities/current-projects/civil-procedure/> (accessed 30 October 2018). 